\title{
Smallholder peri-urban organic farming in Nepal: A comparative analysis of farming systems
}

Gopal Datt Bhatta, ${ }^{a}$ Institute of Agricultural Economics and Related Sciences in the Tropics and Sub-tropics, University of Hohenheim, and Himalayan College of Agricultural Sciences and Technology, Purbanchal University, Nepal

Werner Doppler, ${ }^{\mathrm{b}}$ Institute of Agricultural Economics and Related Sciences in the Tropics and Sub-tropics, University of Hohenheim

Submitted 26 September 2010 / Accepted 16 February 2011 / Published online 11 April 2011

Citation: Bhatta, G. D., \& Doppler, W. (2011). Smallholder peri-urban organic farming in Nepal: A comparative analysis of farming systems. Journal of Agriculture, Food Systems, and Community Development, 1(3), 163-180.

http://dx.doi.org/10.5304/jafscd.2011.013.002

Copyright (C) 2011 by New Leaf Associates, Inc.

\begin{abstract}
Farming in the peri-urban areas of Nepal is increasingly characterized by monocropping and the imprudent use of agrochemicals. This intensification has raised questions about the sustainability of farming systems in the region. In this paper, we do a comparative assessment of these farming systems, focusing on organic production in the densely populated Kathmandu Valley. The relative inaccessibility of farming accessories and of modern farming technologies usually leads rural farmers to follow traditional farming methods, sometimes referred to as "default organic." In contrast, access to infrastructures opens avenues

\footnotetext{
a Institute of Agricultural Economics and Related Sciences in the Tropics and Sub-tropics (490C), University of Hohenheim, 70599 Stuttgart, Germany; and Himalayan College of Agricultel. +0049-711-45923630; bhattagopal@gmail.com

${ }^{b}$ Institute of Agricultural Economics and Related Sciences in the Tropics and Sub-tropics (490C), University of Hohenheim,
} tural Sciences and Technology, Purbanchal University, Nepal; 70599 Stuttgart, Germany; doppler@uni-hohenheim.de
\end{abstract}

for further development of ecological farming in peri-urban areas. Gross margin analysis indicates that organic vegetable production is a lucrative endeavor in the area under study. Urbanites are willing to buy organic vegetables, but the higher price and lack of certification of organically produced vegetables are factors that should be taken into account by producers and organizations working in organic production. We suggest that nongovernmental bodies, along with governmentrun institutions, cooperatives, and communitybased organizations, can play a facilitating role for a smallholder organic growers certification program. They should also support peri-urban farmers in their efforts to enhance the environment and agrobiodiversity.

\section{Keywords}

farm-family income, Nepal, organic vegetables, peri-urban areas, spatial sampling, indigenous knowledge, smallholder 


\section{Introduction}

Urban and peri-urban farming are usually located within or on the fringes of the urban and periurban areas. It has become a very visible economic activity in cities all over the world. In South Asia, some 11 million urban residents are associated with urban and peri-urban agriculture, and it contributes substantially to food security in cities in that region (Van Veenhuizen \& Danso, 2007). By growing foods in the city, financially challenged members of urban society can generate income and also help protect the environment by recycling urban wastes (Cofie, Adam-Bradford, \& Drechsel, 2006;

Midmore \& Jansen, 2003) and make the urban and peri-urban areas more sustainable places to live in (Yves, 2004). Urban agriculture also assists in filling the gap between urban food demand and supply (Umoh, 2006). Additional environmental and human health benefits of urban and peri-urban agriculture include management of solid and liquid city waste, provision of combustion-free zones, management of green space and biodiversity, and improvement of the urban microclimate (Konijnendijk, Gauthier, \& van Veenhuizen, 2004; Midmore \& Jansen, 2003). Peri-urban farmers also assist in reducing the city's ecological footprint by producing fresh foods close to consumers, thereby saving energy during transport and postharvest operations (Van Veenhuizen \& Danso, 2007).

Peri-urban areas (PUAs), however, are subjected to dramatic changes due to urban sprawl, declining farm size, and increasing population density (Van Veenhuizen \& Danso, 2007). Market-driven farming methods, such as shifting from staple and resilient crops toward more perishable vegetable and commercial crops, and increasing marketoriented intensive production, which uses a huge amount of agrochemicals and monocropping, raise many issues pertaining to the sustainability of periurban agriculture (Brook \& Dávila, 2000; Smit, Ratta, \& Nasr, 1996).

In Nepal, agro-inputs such as inorganic fertilizers and pesticides entered into accessible farming areas in the early 1980s, and since then their use has accelerated (Pokhrel \& Pant, 2008). With an increase in the commercialization of vegetable production, there has been a simultaneous growth in pest and disease infestations, resulting in growth in the use of the synthetic pesticides (Pokhrel \& Pant, 2008). Almost 348 tons of active ingredients of pesticides were imported to Nepal in 2007, which was $250 \%$ higher than imports in 2006 (Pesticide Registration and Management Division, 2009). Reports suggest that the use of pesticides in vegetable cultivation in Nepal is higher than in other crops (Koirala, Dhakal, \& Tamrakar, 2009). As compared to other areas such as hills and midhills, the PUAs in the Kathmandu Valley alone account for a huge amount of agrochemicals. Decreasing farmland availability and adverse effects of the inputs used in farming have given birth to organic production (Bhatta, Doppler, \& KC, 2009a). As a result, organic production techniques are becoming popular and are gaining support from producers and consumers alike.

Growing environmental concerns in the 1970s, development of environmental and resource conservation strategies in the 1980s, and implementation of those strategies in the 1990s have made sustainable agriculture a mainstream issue all over the world and organic agriculture an important niche for the development of agriculture. This is particularly true in urban and peri-urban areas (Kotschi, 2010). Organic agricultural practices have shown rapid growth and dynamic development worldwide in recent years and are now practiced in more than 141 countries (Willer \& Klicher, 2009). About one-third of the world's organically managed land - almost 11 million hectares, or over 27 million acres - is located in developing countries. On a global level, organically farmed land area increased by almost 1.5 million hectares (3.7 million acres) from 2006 to 2009, and Asia constitutes $9 \%$ of the world's organic agricultural land (Willer \& Klicher, 2009).

Spatial location of farm families has conspicuous effects on organic farming development (Bhatta, Doppler, \& KC, 2009b). Organic farming development benefits from certain infrastructure and information systems to raise consumers' awareness about the importance of organic food and to create an efficient marketing system for the provision of 
inputs and dispersal of outputs (Aryal, 2008; Bhatta, 2010). These attributes are common in the PUAs, while infrastructure facilities are lacking by and large in rural areas. Peri-urban agriculture in general, and organic farming in particular, are more profitable and sustainable due to nearby large populations, relatively lower transportation costs, and low postharvest losses (Midmore \& Jansen, 2003). In addition, urbanites who are well aware of the harmful effects of pesticide residues, particularly diplomats, tourists, and the well-educated, create a demand for produce free of chemical residues. It has been noted that about $2 \%$ of households in the urban areas of Nepal regularly consume organically cultivated produce, and another $29 \%$ have a desire for its availability (Sharma, 2005). Similarly, urban consumers are willing to pay a premium for organic vegetables (Aryal, Chaudhary, Pandit, \& Sharma, 2009; Bhatta, Ranabhat, \& Subedi, 2008). Thus there is potential for enlarging domestic organic vegetable production and marketing in the urban and peri-urban areas of Nepal.

One of the goals of this research is to explore the unique history of organic farming development in Nepal and the various aspects that should be taken into account to further develop organic farming practices in the PUAs of developing countries. This research is based on a comparative descriptive analysis of the different farming systems (subsistence farming, commercial conventional and smallholder organic vegetable farming), discerning consumer attitudes toward organically cultivated vegetables, and assessing the relevance of smallholder organic farming practices in the PUAs of Nepal. These findings can help urban planners, environmentalists, agriculturists, and development workers in developing countries to understand the capacity of organic farming to improve peri-urban environments and to enhance sustainable food production for city inhabitants.

\section{Development of Organic Agriculture in the Peri-Urban Areas of Nepal}

Many of the rural farmers in Nepal still practice traditional farming methodologies (Sharma, 2005), which may be considered an uncertified "default organic" system (Scialabba, 2000). Although inorganic pesticides were introduced in Nepal as early as 1952 for the control of malaria (Shrestha et al., 2010), the widespread use of inorganic fertilizers and pesticides began in the 1980s (Pokhrel \& Pant, 2008). Government authorities also encouraged farmers to use agrochemicals for higher productivity, and subsequently devised the proproduction policy in the 1980s (Bhatta et al., 2009a). Use of chemical pesticides accelerated after 1983 with the introduction of methyl parathion, a contact pesticide (Sharma, 2005). In the beginning, bags of inorganic fertilizers were distributed free of cost to farmers. The then-village heads and junior technical assistants (JTAs) were forced to distribute a set number of bags of fertilizers. Many farmers buried these bags in their fields to avoid the use of forcibly distributed fertilizers, and many JTAs broadcast fertilizers in the farmers' fields during the night in order to convince the farmers with their results (Sharma, 2005). Farmers realized a better harvest in crops cultivated using fertilizers. This was a turning point in the use of agrochemicals and created a new era of production methods.

Urban farming couldn't ignore the use of the newly introduced agrochemicals. The adopted use of agrochemicals rapidly changed Nepalese from indigenous knowledge-based integrated farming practices to more market-oriented, intensive, and monoculture practices. Introduction of new technologies, use of high-yield varieties, and the commercialization of agriculture have contributed to such changes (Gautam, Upadhyay, Choudhary, $\&$ Khatri, 2004). Road access, along with proximity to input markets, is a precursor of commercial farming (Brown, 2003; Brown \& Shrestha, 2000) and expansion of roads has motivated farmers to continue indiscriminate use of agrochemicals (Bhatta et al., 2009a), leading to agro-ecological degradation. There was a target set by government authorities regarding the usage of fertilizers (NPC, 1995). The import of fertilizers increased significantly after the 1997 Fertilizer Deregulation Policy and the 2002 National Fertilizer Policy were implemented, putting in place subsidies for the transport of fertilizers, particularly for farmers in the hills and mid-hills. 
After almost a decade of using agrochemicals in urban and peri-urban farming, declining yields and increasing pest tolerance have become apparent (Bhatta, 2010). Farmers, who generally have lower literacy levels and are unschooled in the scientific application of agrochemicals, have continued to increase their usage of agrochemicals far above the recommended levels, which complicates the problems further. Some other impacts of agrochemicals include declining soil fertility and negative repercussions on the environment and health of farmers. Grim reminders of the negative repercussions of agrochemicals on farming eventually sparked the movement toward organic production in Nepal, particularly in peri-urban areas (Bhatta \& Doppler, 2010).

Institutionally, scientific and modern methods of organic agriculture in Nepal began with the establishment of the Institute of Sustainable Agriculture in Nepal (INSAN) in 1986 (Sharma, 2008). This is a nongovernmental organization (NGO) working in the PUAs that promotes permaculture, a system similar to organic production. Another milestone of organic production in Nepal was the establishment of the Appropriate Agricultural Alternatives (AAA) farm in Kathmandu Valley in 1987 by an American named Judith Chase. Chase came to Nepal in 1976 to study the functional art of native artists. Chase moved to the countryside of the valley in 1987 to escape the urban lifestyle and experience the rural flavor in the mid-hills of Nepal. Chase began to cultivate vegetables using organic methods in the mid-hills. She soon realized that she could sell all of her produce to the expatriate community at prices twice the normal market prices of fruits and vegetables cultivated using agrochemicals. This enabled her to cover the costs of transportation and management, thus ensuring sustainability of her operation. For a short while, this effort remained isolated, with no sign of being replicated. After a couple of years and with a closer examination of niche marketing opportunities, a new wave of organic agriculture began in the surrounding areas (Weiss, 2004). With the onset of democracy in Nepal in 1990, many NGOs started working on various aspects of organic farming. After 2000, a number of cooperatives and private initiatives based on organic production were also started. As a result, production, productivity, availability, and commerciality of organic agriculture have been trending upward. Since then more than 80 NGOs and private-sector organizations have been involved in promoting organic farming methods in Nepal, particularly in the peri-urban areas (Ghimire, 2005). In the beginning, the authorities of the government of Nepal were reluctant to accept the concept of organic agriculture. However, they soon started their own initiatives to promote organic farming practices once they realized the negative repercussion of farming using agrochemicals.

Certification of organic agricultural produce (particularly of tea, coffee, and some herbal products) began in 1996 (Vaidya, 2006). However, the national norms and standards required for production, inspection, and certification of the organic products are yet to materialize. Some internationally recognized certifying agencies have worked on certification of organically cultivated produce (Pokhrel \& Pant, 2008), especially of highvalue and export-oriented crops. The area under organic production in peri-urban locations is gradually increasing, thanks mainly to the enthusiasm of farmers. That area was around 1,000 ha $(2,471$ acres $)$ in 2005 , and increased to 8,187 hectare $(20,231$ acres) in 2007, of which 7,737 hectare $(19,118$ acres) are fully converted to organic (FiBL \& IFOAM, 2009). There were about 26 registered farms practicing organic production as of 2005 (Shakya, 2005), while 1,424 farms were identified as practicing organic farming methods in 2009 (FiBL \& IFOAM, 2009).

Some supermarkets and grocery shops have started selling organic vegetables, and many restaurants nowadays are serving foods produced from organically cultivated agricultural products. Recently there has been growing interest in promoting organic production and marketing from both government and nongovernment sectors (Pokherel \& Pant, 2009). Demand for organically cultivated vegetables has been increasing in urban areas (Aryal et al., 2009; Bhatta et al., 2009a) due to 


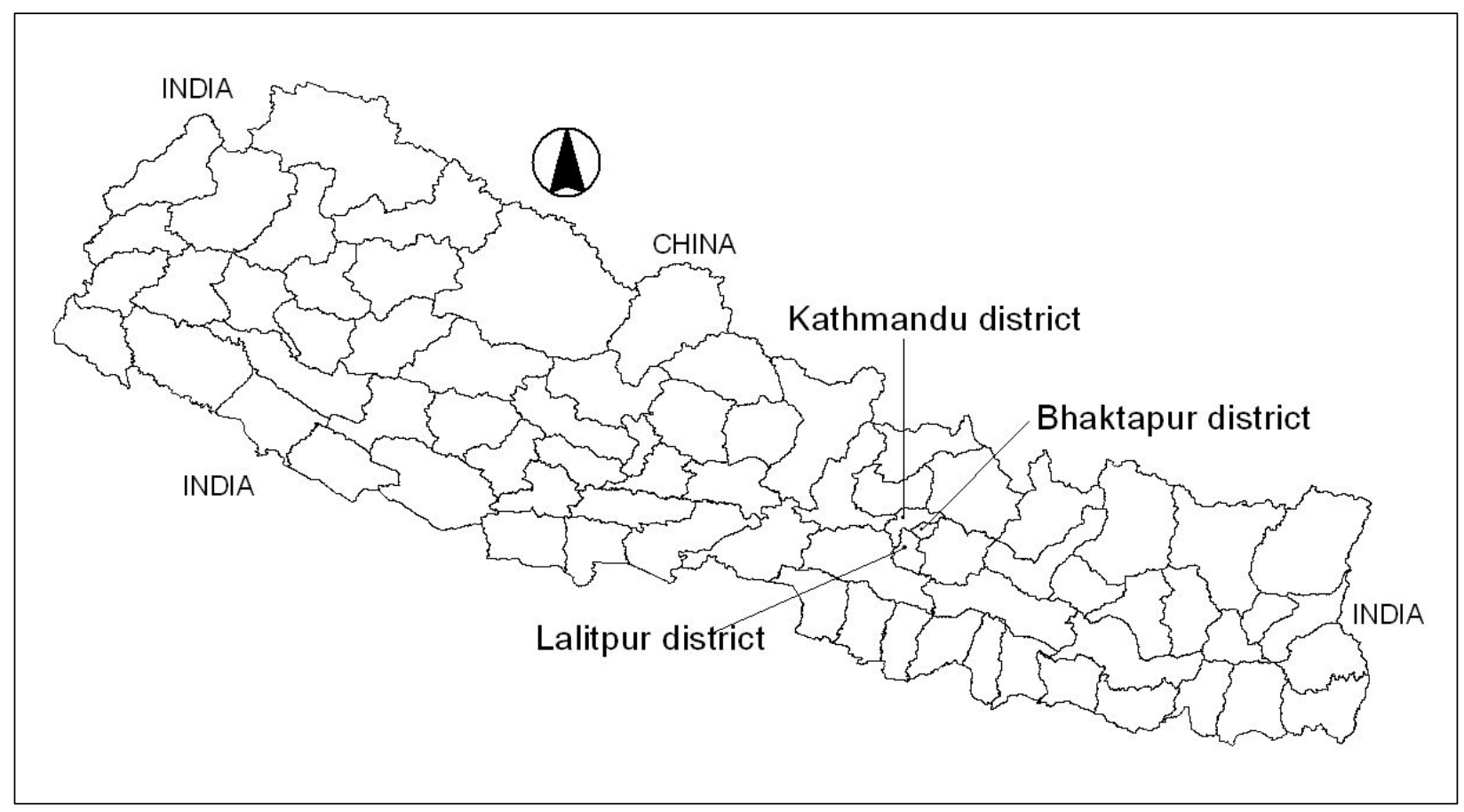

several factors, such as increase in purchasing power, education and awareness about the health and quality of organic foods, and willingness of consumers to eat healthy and safe foods (Bhatta et al., 2009a). However, peri-urban organic agriculture requires partnerships between public and private interests to achieve its potential (Smit et al., 1996).

\section{The Study Area}

The peri-urban areas in and around the densely populated Kathmandu Valley were selected for this study. The valley comprises three districts (figure 1A) situated between the latitudes $27^{\circ} 32^{\prime} 13^{\prime \prime}$ and $27^{\circ} 49^{\prime} 10^{\prime \prime}$ north and longitudes $85^{\circ} 11^{\prime} 31^{\prime \prime}$ and $85^{\circ} 31^{\prime} 38^{\prime \prime}$ east and located at a mean elevation of about 1,300 meters (4,265 feet) above the mean sea level. Figure 1B shows the altitudinal gradients within the study area as represented by the digital elevation model (DEM). The region under study has more than 1.5 million inhabitants, who have access to most elements of urban infrastructure, such as roads, electricity, markets, and information centers (Pant \& Dongol, 2009). Peri-urban farmers of the valley pursue intensive nonorganic and niche market-based organic vegetable production. It has been estimated that close to $23 \%$ of the vegetables consumed in Kathmandu are produced by farmers in the PUAs of the Kathmandu Valley (Pradhan \& Parera, 2005). Similarly, the urban demand for organic vegetables is mostly met by the peri-urban growers in the valley.

In order to make comparisons between the diverse farming systems in the PUAs, three zones with farms using relatively homogeneous farming methods were identified: (i) subsistence farming, (ii) commercial conventional, and (iii) smallholder organic. Parameters such as location, main crops cultivated, degree of market orientation, and production intensity could be used for locating homogeneous production systems in the PUAs (Van Veenhuizen \& Danso, 2007). In order to identify the criteria to define homogeneity in farming practices and to delineate the farming zones used in this study, we explored the site and interviewed local farmers and agricultural experts.

The first criterion used in this study was the degree of market orientation, which was also a criterion used by Nugent (2000) for selecting a homogene- 


\section{Figure 1B. Study Area Represented by the Digital Elevation Model with Road and Market Infrastructures} (elevation expressed in meters above sea level)

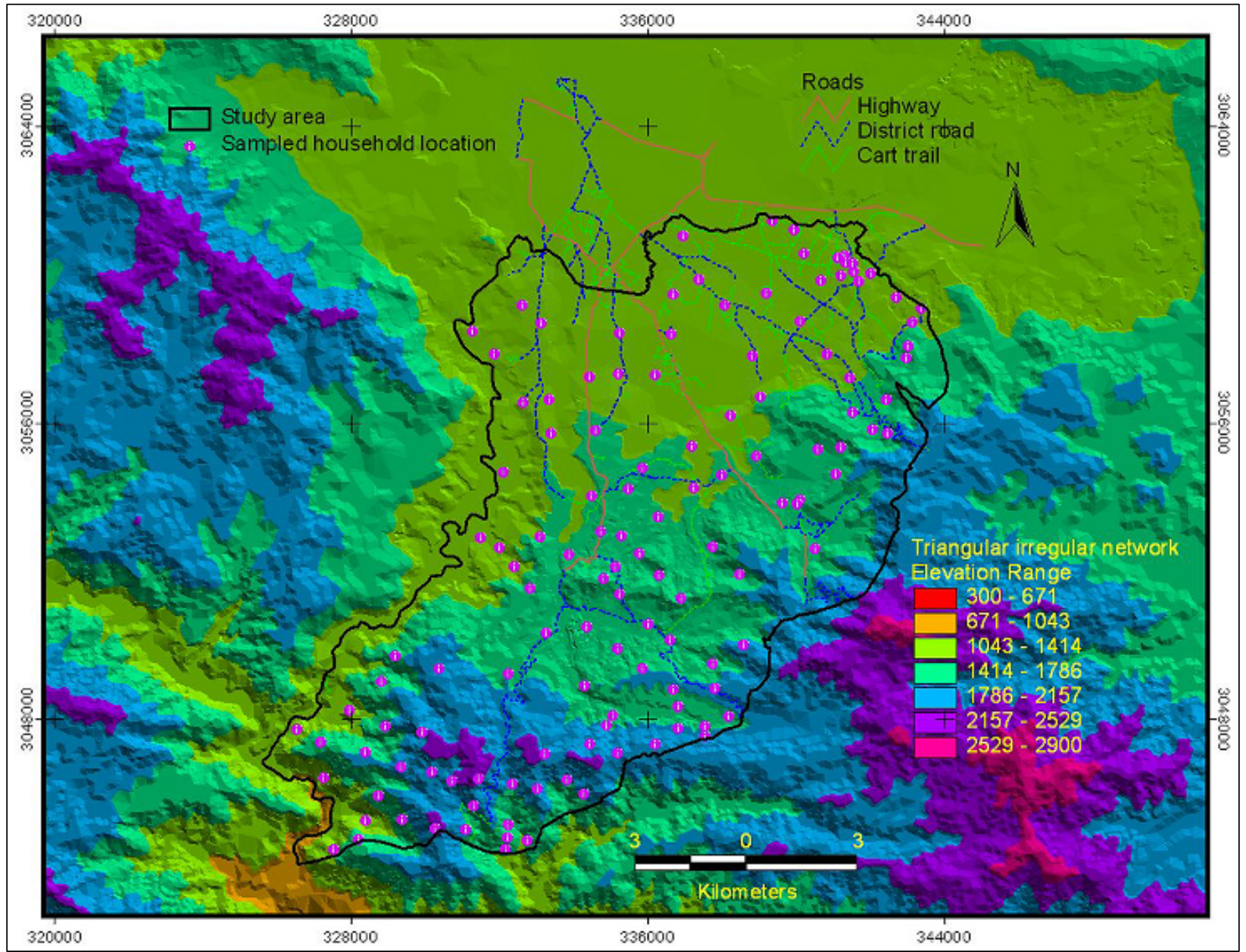

ous group of farmers in the PUAs. It identified a first group of farmers who were mainly subsistence producers using traditional modes of cultivation and almost having no market orientation. These were followed by a second group of farmers who were commercially motivated and were cultivating crops, mainly vegetables, using agrochemicals. The third group comprised farmers who practiced organic methods of vegetable cultivation in a small parcel of land, mainly for niche markets in the urban cores.

The second criterion was related to the biophysical setup of the area under study. It included the slope, altitude, and infrastructure availability (e.g., roads, markets, electricity, and extension services). Look- ing at this criterion, subsistence farming was prevalent in the higher altitude remote areas, some 20 to $25 \mathrm{~km}$ (12.4 to 15.5 miles) away from the urban core, with hilly terrains and relative lack of fundamental infrastructure, while commercial (inorganic) farming was prevalent in the low-lying valley areas where irrigation and infrastructure were in place. Smallholder organic farming was practiced in the middle altitude near the urban market and information center.

The third criterion is related to the practice of farming itself. Subsistence farmers followed traditional farming, often referred to as "organic by default." The integration of forestry and raising of livestock along with raising crops was a common 
feature of subsistence farming. Commercial (conventional) farming was dependent on the use of agrochemicals, while farming was practiced using natural and/or organic inputs in the smallholder (organic) zone. Many farms in this zone had a two-tier production system: organic for the income-generating crops like vegetables, and conventional for the subsistence production.

\section{Sampling and the Data}

The study was based on results of a survey of farm households. The farm households were selected using spatial and random sampling procedures. Through spatial sampling, ${ }^{1} 60$ and 35 farm households were selected from the subsistence and commercial inorganic farming zones, respectively, while 35 farm households from the smallholder organic farming zone were selected through simple random sampling method. All the sampled households in the study area are shown in figure 1B.

The survey of consumers was conducted at the urban organic and conventional vegetable markets in Kathmandu Valley. Using purposive sampling, 100 consumers were selected, 50 each from the local and the specialized markets. ${ }^{2}$ Cattin and Wittink (1982) indicate that the median sample size for finding consumers' preference for particular food product ranges from 100 to 1,000 .

Data were collected using the standard questionnaires (prepared after pretesting) and administered through personal interviews. Two methods were employed to analyze the collected data: (1) Descriptive analysis consisting of calculating percentages over the group, mean, and standard deviation. This also includes the nonparametric tests such as the Mann-Whitney test and group comparison. (2) Gross margin analysis to estimate

\footnotetext{
${ }^{1}$ The spatial sampling method is based on the concept of spatial dependency, which relies on the principle of proximity of locations to one another. Closer locations are expected to have more similar attributes than those farther away (Tobler, 1970).

2 "Specialized markets" include all those markets selling organic vegetables, such as supermarkets, grocery shops, home-delivered groceries, and restaurants offering organic vegetables in their products.
}

the cost and return from key vegetables such as cauliflower. It is given as:

$$
\mathrm{GM}=\mathrm{TR}-\mathrm{TVC}
$$

Where $\mathrm{GM}=$ gross margin, $\mathrm{TR}=$ total revenue, and TVC $=$ total variable cost

\section{Results and Discussion}

\section{Sociodemographic Description of the Respondents}

Efforts were made to understand the sociodemographic characteristics of the peri-urban farmers in the study area. This was done because farming activities are guided mostly by the socio-economic characteristics of the farmers and their families. Most of the respondents interviewed were males, except in the smallholder organic zone. This reflects the patriarchal family structure in which the females are largely responsible for the household and farm activities (Brown, 2003), so they do not have time to give information to the researcher. Even if they have time, they are hesitant. However, the tendency of females to be restricted to household chores is weakening in urban areas. In the cases where males were not available when we were gathering data, we requested to speak with and refer to females.

The educational level of farmers is known to affect their farming activities. Farmers with higher levels of education adopt improved technologies more readily than those with low levels of education (Umoh, 2006). Table 1 (next page) indicates that half the respondents practicing subsistence farming were illiterate, while $31 \%$ of respondents in the commercial conventional and $40 \%$ of respondents in the smallholder organic farming zones were illiterate. This relationship is further supported by the substantially lower percentage of the respondents with higher levels of education in the subsistence farming zone, compared to the sizeable percentage of respondents with higher levels of education in the urban farming zones. The most important factors leading to lower levels of education in the rural areas are lack of access to educational institutions and to public transportation (Thapa \& Murayama, 2010). 
Table 1. Sociodemographic Attributes of the Respondents in Three Farming Zones

\begin{tabular}{|c|c|c|c|}
\hline Variables & $\begin{array}{l}\text { Subsistence } \\
\quad(n=60)\end{array}$ & $\begin{array}{l}\text { Commercial conventional } \\
\qquad(n=35)\end{array}$ & $\begin{array}{l}\text { Smallholder organic } \\
\qquad(n=35)\end{array}$ \\
\hline \multicolumn{4}{|l|}{ Sex (\%) } \\
\hline Male & 68 & 86 & 37 \\
\hline Female & 32 & 14 & 63 \\
\hline \multicolumn{4}{|l|}{ Education (\%) } \\
\hline Illiterate & 50 & 31 & 40 \\
\hline Primary^ & 28 & 23 & 17 \\
\hline Secondary $\ddagger$ & 17 & 34 & 31 \\
\hline Above secondary§ & 5 & 12 & 12 \\
\hline \multicolumn{4}{|l|}{ Marital status (\%) } \\
\hline Married ${ }^{\dagger}$ & 69 & 83 & 81 \\
\hline Unmarried & 31 & 17 & 19 \\
\hline \multicolumn{4}{|l|}{ Main profession (\%) } \\
\hline Farming & 95 & 60 & 54 \\
\hline Government job & 5 & 23 & 26 \\
\hline Job in other sectors ${ }^{\partial}$ & 0 & 17 & 20 \\
\hline \multicolumn{4}{|l|}{ Personal income ("NRs/month) } \\
\hline$<5,000(<$ USD68.49) & 45 & 15 & 12 \\
\hline 5,000-9,999 (USD68.50-USD136.88) & 25 & 20 & 28 \\
\hline 10,000-15,000 (USD137-USD205.50) & 20 & 40 & 30 \\
\hline$>15,000(>$ USD205.50) & 10 & 25 & 30 \\
\hline Age (year) & $42.60(14.38)$ & $42.95(16.60)$ & $43.17(11.95)$ \\
\hline
\end{tabular}

Figures in parentheses after years are standard deviations.

${ }^{\wedge}$ Formal education up to 7 th grade, $\neq$ up to 10 th grade and §above 10th grade

${ }^{\partial}$ Involvement in NGOs, private firms, industries, private schools and colleges, self-employed, etc.

+ Also includes divorced and widowed individuals

ฯ 73 NRs $=1$ USD

Analyzing other sociodemographic characteristics, we found that the PUAs included a higher percentage of married respondents. Farming was the main profession and a key source of income for farmers in the subsistence zone. Although farming still contributes to family livelihoods in the other zones, the share of family income from off-farm work such as government jobs, self-employment, and jobs in the private sector and with NGOs is higher in the more accessible areas. This is because of the centralized governance system and availability of industries and other infrastructures in the urban areas (Thapa, Murayama, \& Bajimaya, 2008). This, in turn, has created various types of jobs for a significant portion of the population (Thapa \& Murayama, 2010).

A majority of the respondents in the subsistence farming zone had low incomes $(<5,000$
$\mathrm{NRs}^{3} /$ month or $<\mathrm{USD} 68.50$ ), while a majority of respondents in the remaining zones had higher incomes (10,000-15,000 NRs/month, or USD137USD205.50). This is due to the respondents' offfarm employment in addition to their farm activities. Most of the farmers in the rural areas have farming activities as their sole source of livelihood. Off-farm employment opportunities are lacking in the rural areas.

\section{Familiarity With and Views of Organic}

\section{Production by Peri-Urban Growers}

Despite the fact that farmers had been following traditional methods of farming for centuries that can be considered "organic by default" in the subsistence farming areas, a majority of the

\footnotetext{
${ }^{3}$ NRs: Nepalese rupees; 1 USD $=73$ NRs.
} 
farmers are still not aware of the term "organic farming." Farming in these areas was based on use of local resources. A majority of the subsistence farmers had never used agrochemicals in their farming, either due to the lack of inputs and the farmer's inability to afford them, and/or a lack of knowledge about their availability and use. Many farmers in the commercial inorganic and smallholder organic farming zones had already heard of organic farming, and the percentage of farmers who had heard of it was higher in the smallholder organic farming zone (see figure 2). This is likely because most of the farmers there had been engaged in organic production, and many developmental organizations were generating awareness about organic and ecological farming in this area.

Considerable confusion surrounding the term "organic" still exists among the farmers in the PUAs (Bhatta, 2010). Application of farmyard manure as a source of nutrients would be considered an organic practice by farmers in the subsistence zone (table 2). Most of the farmers in this zone relied on farmyard manure because the
Figure 2. Are Respondents Acquainted with Organic Farming ?

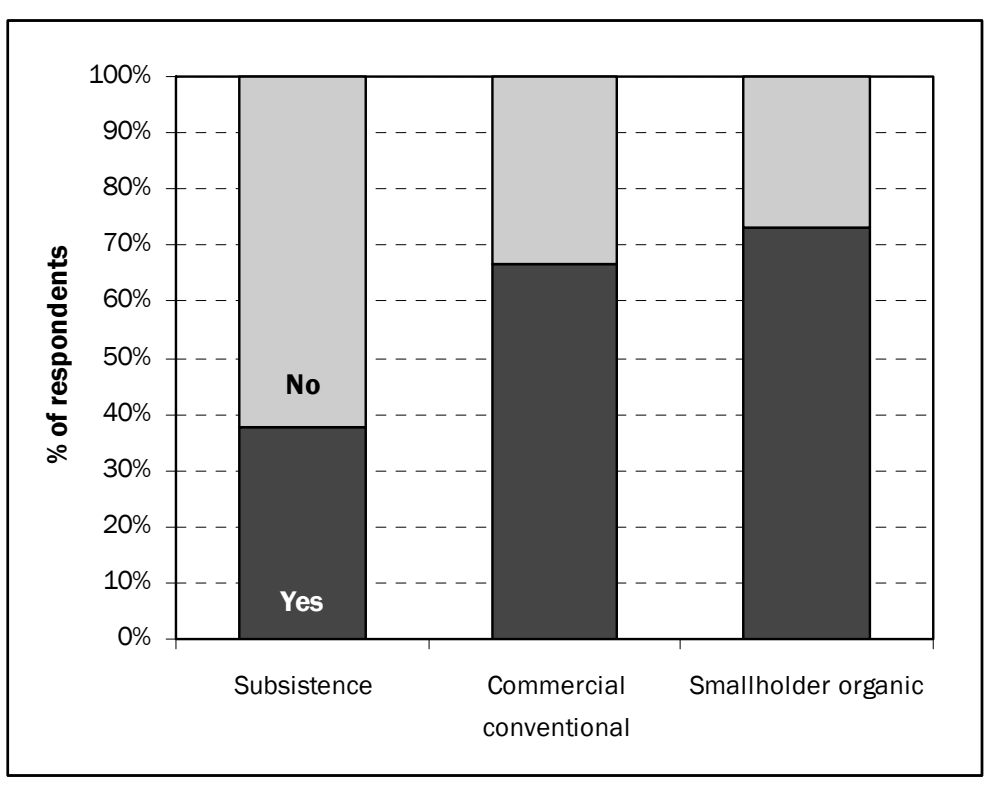

Table 2. Farmer's Perception of Organic Farming Practices in the Peri-Urban Areas

\begin{tabular}{|c|c|c|c|}
\hline \multirow[b]{2}{*}{ Farmer's knowledge of organic farming } & \multicolumn{3}{|c|}{ Percentage of respondents } \\
\hline & $\begin{array}{l}\text { Subsistence } \\
\qquad(\mathrm{n}=60)\end{array}$ & $\begin{array}{l}\text { Commercial } \\
\text { conventional }(n=35)\end{array}$ & $\begin{array}{l}\text { Smallholder organic } \\
\qquad(n=35)\end{array}$ \\
\hline No use of chemicals in farming & 26.1 & 34.8 & 19.2 \\
\hline Use of farmyard manure only & 43.5 & 0 & 0 \\
\hline No use of urea in farming & 8.7 & 0 & 0 \\
\hline Use of farm manure, environmentally safe & 8.7 & 26.1 & 3.8 \\
\hline Traditional agriculture & 8.7 & 4.3 & 0 \\
\hline No use of pesticides in farming & 0 & 8.7 & 3.8 \\
\hline Adoption of Integrated Pest Management techniques & 0 & 4.3 & 7.7 \\
\hline $\begin{array}{l}\text { Farming using local resources, quality production, and is } \\
\text { safe for health and the environment }\end{array}$ & 4.3 & 21.7 & 57.7 \\
\hline Products for foreigners and rich people & 0 & 0 & 7.7 \\
\hline
\end{tabular}


Table 3. Importance and Benefits of Organic Agriculture as Perceived by Respondents

\begin{tabular}{lc}
\hline Importance and/or benefits realized & $\begin{array}{c}\text { \% of respondents } \\
(\mathrm{n}=66)\end{array}$ \\
\hline For health benefit/chemical-free products & 33.33 \\
Use of local resources & 18.17 \\
Maintenance of soil fertility & 15.15 \\
Conservation of nature & 13.64 \\
Independence on obtaining external resources & 9.09 \\
Lower cost of production & 7.78 \\
Earning foreign currency & 3.02 \\
\hline
\end{tabular}

the reason why farmers in this zone were motivated to use organic production. Most of the farmers in the commercially inorganic farming zone held the same view as those cultivating in the subsistence farming zone.

While most of the farmers in the area where farming is organic by default had heard of and were aware of organic farming practices, particularly the use of local resources in farming for producing quality products, most of them were still unfamiliar with organic standards or organic certification. For them, lower production costs, proper soil management, avoidance of toxic substances and agrochemicals, self-reliance in inputs, and harmony with nature were the main motivating factors for practicing organic farming methods. The above explanation highlights the rudimentary stage of organic farming practice. However, farmers' motivations related to ecological conservation, supported by NGOs, have fueled the organic movement in the region and have shown better prospects in Nepal.
Figure 3. Existing Organic Vegetable Marketing Channels in the Kathmandu Valley

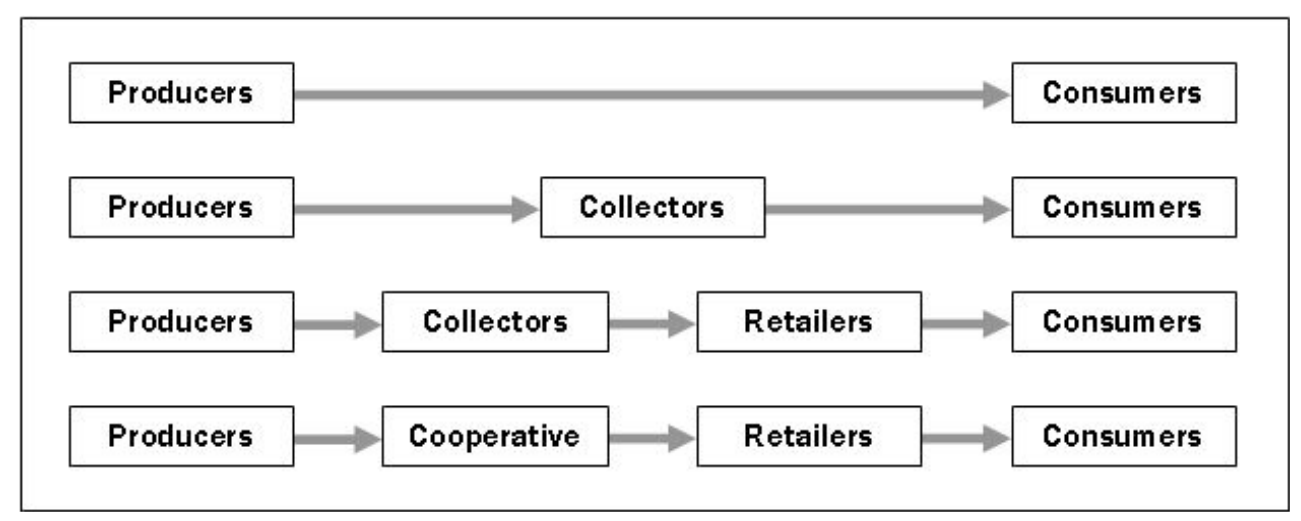

Motivations for Organic Farming in the Peri-Urban Areas

The intensified use of agrochemicals has affected and is further expected to affect surrounding natural resources, either directly or indirectly. Farmers are now realizing the need to care for the soil, their own health, the health of their family members, and also the health of their consumers, and they feel they can do this by curtailing the amounts of agrochemicals they use or by avoiding their use entirely. With this awareness, most of the farmers following conventional farming have shown their willingness to shift from their present farming practices.

Table 3 ranks the benefit or importance of various aspects of organic farming as listed by the respondents. A majority of the farmers opined that organic farming is important for health, as the agricultural produce obtained using organic methodologies are free from agrochemical residues and are thus safe for consumption. The second important issue, highlighted by nearly $18 \%$ of the farmers, was that organic farming is important for efficient use of local resources. Some other benefits realized by the farmers were maintenance of soil fertility, conservation of nature, independence from the use of external resources, and a lower cost of production.

Marketing of Organically Cultivated Vegetables Marketing of vegetables cultivated using organic methodology is characterized by scattered 
concentrations of consumers, lack of awareness about the existence of organic products in the market, lack of credibility of organic products, and lack of market regulation (Bhatta et al., 2009a). Marketing channels for organic vegetable were relatively simple, involving only few intermediaries (see figure 3).

Four prominent channels of organic vegetables marketing have been observed to be prevalent in the Kathmandu Valley. The common market chains include producers, collectors, ${ }^{4}$ retailers, cooperatives, and consumers. The most important marketing channel for organic vegetables in PUAs was cooperatives (table 4). Cooperatives, most of which are functional groups of local farmers, play a predominant role in Nepalese society. Generally, these cooperatives have multiple roles in the community. In addition to marketing the organic vegetables, they also play a role as microfinance institutions, assisting the producers by providing small but timely credit. The linkage between producers and consumers through direct home delivery of produce follows the cooperative channel. In this case, growers themselves deliver the volume of vegetables that were ordered to the consumers. The cultivators have direct contact with the consumers and vice versa. Most of the vegetables cultivated using the organic methods are marketed based on earlier agreements between traders and producers; the agreements are often contractual in nature, which indicates the dominance of the traders in the channel. In general, consumers who received home delivery are from the upper strata of society and were of the opinion that the vegetables supplied to them were cultivated following the organic methodology. Therefore, they are more willing to pay for home-delivered produce. When collectors were involved in marketing the organic vegetables, they were either local traders or local organic growers who collected from the specified

\footnotetext{
${ }^{4}$ A "collector," common terminology in many developing nations in Asia, collects vegetables from individual farmers and then supplies them to different channels.
}

community and sold to the retail shops in the heart of the city.

Currently, organically produced vegetables cost $50 \%$ to $100 \%$ more than their nonorganic counterparts. These high-priced vegetables are mostly unaffordable to less affluent consumers (Aryal et al., 2009). Table 5 (next page) indicates that almost $60 \%$ of consumer respondents were willing to buy vegetables cultivated by organic methods, provided they were informed about the benefits of organic production. Almost $47 \%$ of the respondents said that price was an important factor when considering purchase of organically cultivated vegetables. Almost $78 \%$ of the respondents indicated that they would be willing to buy organic vegetables if their prevailing price were reduced by $20 \%$ to $30 \%$. This indicates the potential for large-scale production of vegetables cultivated through organic means to moderate the general price of organic produce. There is also a need to disseminate knowledge and create awareness among consumers about organic vegetables.

In regard to certification and labeling, a majority of consumers said that these are essential for enlarging the market for organically cultivated vegetables and assisting in appealing to consumers. Currently, organic vegetables are not certified. Therefore consumers have been circumspect in their faith in these products. Various studies have demonstrated that the presence of a label instrument or indicator that guarantees the quality of the product significantly affects consumers' preference (Misra, Huang, \& Ott, 1991; Schupp \& Gillespie, 2001; Souza \& Ventura, 2001). This implies that certification and labeling are needed to convince 
Table 5. Consumer Attitudes Toward Organic Vegetables (\% distribution, $n=100$ )

\begin{tabular}{|c|c|c|c|c|}
\hline & \multicolumn{4}{|c|}{ Alternatives } \\
\hline & Extremely (1) & Somewhat (2) & Somewhat (3) & Don't know (4) \\
\hline $\begin{array}{l}\text { How willing are you to buy organic vegetables from the } \\
\text { market? }\end{array}$ & 60.0 & 37.8 & 2.2 & 0.0 \\
\hline $\begin{array}{l}\text { How willing are you to consume organic vegetables if their } \\
\text { prices are reduced? }\end{array}$ & 77.8 & 22.2 & 0.0 & 0.0 \\
\hline $\begin{array}{l}\text { How important is the price factor when you decide whether } \\
\text { to buy organic vegetables? }\end{array}$ & 46.7 & 37.8 & 5.6 & 10.0 \\
\hline $\begin{array}{l}\text { How willing would you be to purchase organic vegetables if } \\
\text { you knew they were safer for health? }\end{array}$ & 90.0 & 10.0 & 0.0 & 0.0 \\
\hline How safe or risky are organic vegetables to human health? & 50.0 & 44.5 & 0.0 & 5.5 \\
\hline How important is it to certify and label organic vegetables? & 71.1 & 21.1 & 0.0 & 7.7 \\
\hline $\begin{array}{l}\text { How willing would you be to pay for environmental services } \\
\text { (PES) of organic production if you knew inorganic methods } \\
\text { of farming were environmentally degrading? }\end{array}$ & 80 & 15 & 0.0 & 5.0 \\
\hline
\end{tabular}

Note: 1, 2: willing/important, 3: unwilling/unimportant

consumers to buy and for farmers to get a reasonable price for the produce.

Potential health hazards resulting from excessive and indiscriminate use of agrochemicals have been indicated by Midmore \& Jansen (2003). Nearly $80 \%$ of the consumers were aware of these potential hazards and were willing to contribute toward the "pay for environmental services" (PES). PES is the practice of offering incentives to farmers, communities, and economies in exchange for managing their lands to provide ecological services (Boyd and Benzhaf, 2006). Several factors lead to a growth in demand and willingness to pay for environmental services. Public awareness of the value of environmental services is the most important factor that stimulates PES (FAO, 2007). Smallholder farmers in the developing world can be efficient producers of environmental services of value to larger communities and societies (Swallow, Meinzen-Dick, \& Noordwijk, 2005). Relative to monocropping, positive effects on biodiversity have been noted for a variety of farming practices including organic agriculture and conservation farming (McNeely \& Scherr, 2003). Willingness of the consumers to comply with PES through organic vegetable production to reduce the city's ecological footprint could be another aspect that defines the apparent potential of organic farming in the PUAs.

\section{Gross Margin Analysis of Vegetables}

The scope of agriculture production can be expanded and sustained by farmers through efficient use of resources. Efficiency measurement is also an important subject of empirical investigation, mainly in the developing countries, where a majority of the farmers are resource-poor (Umoh, 2006). Gross margin analysis helps assess the performance of individual crops or an enterprise (Wachholtz, 1996). It can also find the most efficient crops, cropping pattern, or enterprise.

In this study, different types of vegetables were cultivated by farmers in the different zones; the crop chosen also depended on the needs of the family cultivating it and on the market demand for it. Only a few vegetables, such as cauliflower, cabbage, tomatoes, potatoes, chilies, leafy vegetables, and cucurbits, are usually cultivated in the inorganic or commercial zone, while diverse vegetables, including asparagus, lettuce, Swiss 
Table 6. Gross Margin of Different Types of Vegetables in the Study Zones, 2008

\begin{tabular}{|c|c|c|c|}
\hline Variables & $\begin{array}{l}\text { Subsistence } \\
\quad(n=15)\end{array}$ & $\begin{array}{l}\text { Commercial conventional } \\
\qquad(n=20)\end{array}$ & $\begin{array}{l}\text { Smallholder organic } \\
\qquad(n=30)\end{array}$ \\
\hline $\begin{array}{l}\text { Variable cost } \\
\text { (NRs§) }\end{array}$ & $942^{c}( \pm 386)$ & $4213^{a}( \pm 779)$ & $3297^{b}( \pm 245)$ \\
\hline $\begin{array}{l}\text { Gross margin per unit of land } \\
\text { (NRs/ropani) }\end{array}$ & $3841^{b}( \pm 1262)$ & 20659a $( \pm 7220)$ & $25748^{a}( \pm 2756)$ \\
\hline $\begin{array}{l}\text { Gross margin per unit of labor used } \\
\text { (NRs/man-day) }\end{array}$ & $219.60^{\mathrm{b}}( \pm 58.2)$ & $772.42^{\mathrm{a}}( \pm 330.78)$ & $690.34^{a}( \pm 77.25)$ \\
\hline $\begin{array}{l}\text { Gross margin per unit of variable cost } \\
\text { (NRs/variable cost) }\end{array}$ & $4.84^{b}( \pm 1.42)$ & $4.97^{b}( \pm 1.62)$ & $7.89^{a}( \pm 0.74)$ \\
\hline
\end{tabular}

Note: Figures in the parentheses are $95 \%$ confidence interval of the mean; superscripted letters show significant difference between the groups at $5 \%$ level of significance according to the Mann-Whitney test. Values with similar letters are not significantly different. $\S 73$ NRs $=1$ USD

chard, fenugreek, pea, cowpea, and celery, which fetch a higher market value, are usually cultivated organically in addition to all the vegetables cultivated using agrochemicals. In the subsistence farming zone, farmers cultivated tomatoes, potatoes, cucumber, pumpkin, onion, coriander, and ginger. The results thus indicate that organic farms have greater agro-biodiversity, while inorganic farms tended to accommodate only a few crop species.

Gross margin analysis of vegetables was carried out by converting the yields of the individual crop into the crop-equivalent yields of cauliflower, as this was the most important vegetable crop cultivated by both organic and inorganic growers. ${ }^{5}$ Gross margin per hectare was significantly higher in the smallholder organic farming system and was at par with the commercial inorganic zone (table 6). The

\footnotetext{
${ }^{5}$ We collected the market price and yield of several vegetables produced by the farmers. It is not possible to analyze each of the crops produced by farmers since most produce over a dozen kinds of vegetables. Therefore, for the sake of convenience and in order to have uniform measurement, cauliflower yield for each crop was calculated using prices and yields of all crops. For instance, the cauliflower yield of radish was calculated using this formula:

Cauliflower-equivalent yield of radish $=$

Yield of cauliflower + (Yield of radish $\times$ Price of radish)
}

Price of cauliflower higher gross margin in the organic group is due to the diverse vegetable species produced with their higher prices in the niche market. Gross margin of labor was higher in the commercial conventional farming, which was at par to the smallholder organic farming, and both of them were significantly higher than in the subsistence farming. Return per rupee invested on vegetable production was significantly higher for the vegetables cultivated using the organic methodologies than for the others. This proves that resource-use efficiency was higher with organic vegetable production.

Higher gross margin per hectare and per unit of variable cost on the farms where the vegetables are cultivated using organic methods also indicate that organic methods of cultivation can be a lucrative enterprise. Relatively higher gross margin per hectare was associated with organic vegetables, along with positive environmental externalities such as amelioration of the urban environment, providing safe and healthy foods, and enhancing agro-ecology. This supports the idea that organic farming can be a perfect match in peri-urban settings of developing nations, and Nepal is no exception to this.

\section{Farm-Family Income}

Farm income generally comes from sales of food crops, vegetables, and livestock. Food crops include cereals such as rice, wheat, maize, and 
Table 7. Structure of Farm-family Income in the Study Zones, 2008

\begin{tabular}{|c|c|c|c|}
\hline & \multicolumn{3}{|c|}{ Farm-family income (NRs\$/family/year) } \\
\hline & $\begin{array}{l}\text { Subsistence } \\
\quad(n=60)\end{array}$ & $\begin{array}{l}\text { Commercial conventional } \\
\qquad(n=35)\end{array}$ & $\begin{array}{l}\text { Smallholder organic } \\
\qquad(n=35)\end{array}$ \\
\hline Total farm revenue & $93,122( \pm 19,547)$ & $102,767( \pm 24,343)$ & $98,082( \pm 26,695)$ \\
\hline Food crop revenue & $49,996 \mathrm{ab}( \pm 12,987)$ & $56,578^{a}( \pm 18,026)$ & $35,223^{b}( \pm 8,080)$ \\
\hline Vegetable crop revenue & $7,421^{c}( \pm 5,125)$ & $30,514^{b}( \pm 14,268)$ & $47,364^{a}( \pm 15,236)$ \\
\hline Livestock revenue & $35,705^{a}( \pm 9,808)$ & $1,5674^{\mathrm{b}}( \pm 8,790)$ & $15,496^{b}( \pm 11,751)$ \\
\hline Total farm expense & $36,476( \pm 5,940)$ & $37,569( \pm 8,252)$ & $35,008( \pm 11,771)$ \\
\hline Farm income & $56,646( \pm 15,681)$ & $65,198( \pm 17,346)$ & $63,073( \pm 20,790)$ \\
\hline Farm income/ha food crops & $52,660^{\mathrm{b}}( \pm 12,781)$ & $134,334 a( \pm 40,487)$ & 123,033 a $( \pm 30,536)$ \\
\hline Farm income/ha vegetable crops & $289,008^{b}( \pm 178,721)$ & $443,963^{\mathrm{b}}( \pm 197,462)$ & $862,294^{a}( \pm 201,790)$ \\
\hline Farm income/family labor unit & $15,217^{a}( \pm 3,514)$ & $23,623^{\mathrm{b}}( \pm 6,568)$ & $19,907 \mathrm{ab}( \pm 5,845)$ \\
\hline Off-farm income & $72,550^{b}( \pm 23,974)$ & $169,386^{b}( \pm 74,593)$ & $354,117 a( \pm 185,672)$ \\
\hline Family income & $129,196^{b}( \pm 33,879)$ & $234,583^{b}( \pm 72,829)$ & $417,188^{a}( \pm 187,391)$ \\
\hline Family income/family member & $18,160^{\circ}( \pm 3,496)$ & $42,458^{b}( \pm 11,361)$ & $67,009 \mathrm{a}( \pm 25,156)$ \\
\hline
\end{tabular}

Note: Figures in the parentheses are 95\% confidence interval of the mean; superscripted letters show the significant difference between groups at 0.05 level of probability according to the Mann-Whitney test. Values with similar letters are not significantly different.

$\S$ Nepali currency (73 NRs $=1$ USD)

some other coarse cereals ${ }^{6}$ like buckwheat and millets, legumes, and oilseed. Table 7 shows farmfamily income under different methods of cultivation. The results show that in subsistence farming areas, a large portion of farm revenue was generated from cereal crops $(53.69 \%)$ and livestock (38.34\%), while in the commercial inorganic and smallholder organic farming, a major portion of income was obtained from cereals $(55.06 \%)$ and vegetable crops $(48.29 \%$ ). Significantly higher revenue was generated from vegetable crops in smallholder organic farming, because this is the zone where diverse and high-value species of organic vegetable are usually cultivated. Similarly, higher revenue from livestock was obtained from subsistence farming. This may be because dairy farming is usually given high priority in this zone.

\footnotetext{
${ }^{6}$ These are the crops grown by resource-poor farmers and on land which is not suitable for cultivation of rice, wheat, and maize (major cereals in Nepal). Sometimes coarse cereals are called "the poor men's food" (Rajbhandari \& Bhatta, 2008).
}

Furthermore, integration of agriculture with livestock and forestry is a rule of thumb in subsistence farming. This integration is very important in rural areas due to lack of access to improved inputs such as fertilizers.

Farm income per hectare of food crops cultivated was significantly higher on the commercial (nonorganic) farms and was at par with the smallholder organic farms, while farm income per hectare of the area under vegetable cultivation was significantly higher in the smallholder (organic) farming. It was almost two or three times higher than that obtained by commercial nonorganic and subsistence farming systems, respectively. This further indicates that there are better prospects for vegetables cultivated organically in this area. Farm income per family member was significantly lower in subsistence farming. This may be due to the larger family size of the cultivators in this group. Farm income per family member employed on the farm also followed a similar trend, while family 
income per family member was significantly higher in smallholder organic farming.

Off-farm income was mainly generated from salaries obtained by the cultivators in all the zones studied. The contribution was significantly higher in the smallholder organic farming group. This may be because most of the smallholder family members had a higher level of education and they were near the centers of opportunity. Significantly higher income from wages was obtained by the farmers in the subsistence group, as many of the family members were poorly educated and employment opportunities were limited. Significantly higher income through enterprise and business was obtained by the smallholder organic farmers. In this group, some of the farmers had a poultry farm and some had a small- or medium-sized shop.

Family income was significantly higher for the smallholder organic farms, while the remaining two groups were at par. The contribution to family income from farm income was $45 \%$ in the subsistence group, while it was almost $30 \%$ for the commercial inorganic farms, and $15 \%$ for the smallholder organic farms. This clearly demonstrates that farming is getting less attention and offfarm activities are gaining prominence in the PUAs, whereas agriculture is still a mainstay of the livelihoods of rural people.

Figure 1B, above, also shows that year-round accessible roads do not exist in the rural areas, while extensive and good-quality roads are available in most part of the PUAs. In the rural areas, the quality of roads is very poor and vehicles are not able to navigate them all year. The market externalities associated with such roads are extremely high compared with that of the PUAs (Bhatta et al., 2009b). In addition there is a conspicuous lacking of effective extension services in rural areas. These are some of the key reasons why rural farming still remains traditional, and such a vast array of "organic by default" cannot be promoted as niche market-based organic production. In contrast, because of the greater accessibility of fundamental urban amenities coupled with consumer willingness to pay more for organic products, market-based organic production is thriving in the peri-urban areas.

\section{Conclusions}

Gross margin and farm-family income analyses show that smallholder organic production in periurban areas (PUAs) is a profitable endeavor. Urban locations are suffering from environmental damage due to imprudent farming practices and pollution caused by urban sprawl. Therefore, organic production is one of the best strategic approaches to both minimize this ecological degradation and to provide better returns for smallholder producers. The high potential for organic farming in the PUAs is also buttressed by the farmers' inclinations toward organic production, the availability of niche markets, increasing consumer awareness, and consumer willingness to pay more for organic products. The fact that organic production in the PUAs is initiated, motivated, and promoted by NGOs, but supported and continued by farmers, also indicates that organic production has a strong potential to proliferate.

\section{Recommendations}

Considering the broad agro-ecological and environmental benefits of organic farming in the PUAs, the Nepalese government should subsidize organic producers, at least during the conversion period. This would motivate growers already using organic methods and also attract their fellow farmers to pursue organic cultivation methods. Imprudent agro-chemical-based farming is undesirable. If it is allowed to continue in the urban and peri-urban areas, it will have undesirable effects on urban dwellers. Therefore, organic production and marketing should be strengthened in order to keep soil healthy and foods free from chemical residues. Furthermore, a campaign to raise awareness should be initiated in order to make all stakeholders in the food system aware of the negative repercussions of agrochemical-based farming and the need for production and consumption of organic foods.

Consumers' interest in organic vegetables shows that price and certification are the decisive factors. However, certification is a very costly affair. The higher cost of production of organic vegetables, 
accompanied by the cost of organic certification, increases the price of organic commodities.

Similarly, as a majority of peri-urban growers are smallholders, it is not economical for them to seek certification as individual farms. Therefore, attempts should be made to consolidate smallholders' organic farms and initiate cooperative certification through internal quality-control systems in order to minimize the costs of complying with organic standards, particularly for the local market. Similarly, participation in and promotion of organic production would require awarenessraising, motivation, and training among the growers, consumers, and marketers. This should be done by the governmental and nongovernmental organizations working to promote organic farming.

The ability of fringe agriculture to continuously supply food for urbanites will depend on better planning and focusing socio-economic and spatial aspects of smallholder farm families. Spatial aspects such as lack of access to roads would be given due consideration, and roads and transportation systems should be improved. This would help transform "organic by default" into niche marketbased organic production, and hence provide benefits to rural farmers living in the peri-urban hinterlands.

\section{Further Research}

This study focuses on the peri-urban settlements of the Kathmandu Valley. The finding of this research might be applicable to similar areas, particularly in the densely populated PUAs in the developing world. High-value crops with international trade implication, such as tea, coffee, cardamom, ginger, and herbal products, are grown organically in some of the PUAs of Nepal. Research focusing on multiple products is also needed to give a broader picture of the organic movement in the PUAs and its future implications in socio-economic and spatial realms. Similarly, research that focuses mainly on organic farming in the peri-urban areas and attempts to quantify the positive externalities it generates is also needed to further justify the adoption of organic farming methods. The concerns about higher prices and the legitimacy of certification should be also duly incorporated in the research agenda.

\section{Acknowledgement}

We acknowledge financial support provided by the DAAD to conduct this research. We also thank the anonymous JAFSCD reviewers for their constructive suggestions and comments for imparting better quality to this manuscript.

\section{References}

Aryal, K. P. (2008). General perceptions of producer, traders and consumers about organic products in Kathmandu Valley. In P. Chaudhary, K. Aryal, \& D. Tharu (Eds.), Proceedings of International Workshop on Opportunities and Challenges of Organic Production and Marketing in South Asia (pp. 120-124). Kathmandu, Nepal: Nepal Permaculture Group.

Aryal, K. P., Chaudhary, P., Pandit S., \& Sharma, G. (2009). Consumers' willingness to pay for organic products: A case from Kathmandu Valley. Journal of Agriculture and Environment, 10, 12-22.

Bhatta, G. D. (2010). Bio-farming and marketing in Nepal: Through producer, consumer, trader and spatial perspectives. In W. Doppler and K. B. KC (Eds.), Farming and rural systems economics and biodiversity in the tropics (pp. 167-190). Germany: Margraf Publishers.

Bhatta, G. D. \& Doppler, W. (2010). Farming differentiation in the rural-urban interface of the Middle Mountains, Nepal: Application of analytic hierarchy process modeling. Journal of Agricultural Science, 2(4), 37-51.

Bhatta, G. D., Doppler, W., \& KC, K. B. (2009a). Potential of Organic Agriculture in Nepal. Journal of Agriculture and Environment, 10, 1-11.

Bhatta, G. D., Doppler, W., \& KC, K. B. (2009b). Spatial differentiation in farming practices and their impact on rural livelihood: A case from hills of Nepal. In E. Tielkes (Ed.), Book of abstracts, bio-physical and socio-economic frame conditions for the sustainable management of natural resources ( $p$. 509). Hamburg, Germany.

Bhatta, G. D., Ranabhat, A., \& Subedi, M. (2008). Consumers' awareness and willingness to pay for organic vegetables in the Kathmandu Valley. Green Field Journal, 6, 62-78.

Boyd, J. \& Benzhaf, S. (2006). What are ecosystem services? The need for standardized environmental accounting units. Discussion Paper, RFF DP 06-02. Washington, DC: Resources for the Future. 
Brook, R. M., \& Dávila, J. D. (Eds.). 2000. The peri-urban interface: A tale of two cities. School of Agricultural and Forest Sciences, University of Wales and Development Planning Unit, University College, London.

Brown, S. (2003). Spatial analysis of socio-economic issues: Gender and GIS in Nepal. Mountain Research and Development, 23(4), 338-344. doi:10.1659/02764741(2003)023\%5B0338:SAOSIG\%5D2.0.CO;2

Brown, S., \& Shrestha, B. (2000). Market driven land use dynamics in the Middle Mountains of Nepal. Journal of Environment Management, 59, 217-225. doi:10.1006/jema.2000.0355

Cattin, P., \& Wittink, D. R. (1982). Commercial use of conjoint analysis: A survey. Journal of Marketing, 46, 44-53. doi: $10.2307 / 1251701$

Cofie, O., Adam-Bradford, A., \& Drechsel, P. (2006). Recycling of urban organic waste for urban agriculture. In R. van Veenhuizen (Ed.). Cities farming for the future: Urban agriculture for green and productive cities. Leusden: RUAF

Foundation/IDRC/IIRR.

Food and Agriculture Organization of the U.N. (FAO). (2007). Paying farmers for environmental services. World and Regional Overview. Rome: Food and Agriculture Organization of the United Nations.

FiBL \& IFOAM. (2009). Global organic agriculture statistics. The Organic-World.Net homepage, The Research Institute of Organic Agriculture (FiBL), Frick, retrieved from http://www.organic-world.net/ statistics.html

Gautam, I. P., Upadhyay, K. P., Choudhary, J. N., \& Khatri, B. (2004). Study on intercropping vegetables in maize-based cropping system in Tar area of western Nepal. Proceedings of IV National Conference on Science and Technology, Royal Nepal Academy of Science and Technology (RONAST), (pp. 110-114), Kathmandu, Nepal.

Ghimire, M. (2005). Organic agricultural product certification in Nepal (process and practices). In G. Sharma \& P. Thapa (Eds.), Proceedings of workshop on organic agriculture and food security. Kathmandu, Nepal: Nepal Permaculture Group.

Koirala, P., Dhakal, S., \& Tamrakar, A. S. (2009). Pesticides and food safety issues in Nepal. Journal of Agriculture and Environment, 10, 33-36.

Konijnendijk, C., Gauthier, M., \& van Veenhuizen, R. (2004). Trees and cities, growing together (Editorial). Urban Agriculture Magazine, 13.

Kotschi, J. (2010). Poverty alleviation in the south can organic farming help? AGRECOL, Marburg,
Germany. Retrieved from http://www.agrecol.de/ dokumente/ifoam_jk.pdf

McNeely, J. A., \& Scherr, S. J. (2003). Ecoagriculture. Washington, DC: Island Press.

Midmore, D. J., \& Jansen, H. G. P. (2003). Supplying vegetables to Asian cities: Is there a case for periurban production? Food Policy, 28, 13-27. doi:10.1016/S0306-9192(02)00067-2

Misra, S., Huang, C., \& Ott, S. (1991). Consumer willingness to pay for pesticide free fresh produce. Western Journal of Agricultural Economics, 16, 218-227.

National Planning Commission (NPC). (1995). Nepal agriculture perspective plan. National Planning Commission, Nepal and Asian Development Bank TA No. 1854-Nep.

Nugent, R. (2000). Urban and periurban agriculture, housebold food security and nutrition. Discussion paper for the FAO-ETC/RUAF electronic conference, Urban and peri-urban agriculture on the policy agenda, retrieved from http://www.fao.org/urbanag

Pant, P. R., \& Dongol, D. (2009). Kathmandu Valley Profile_-Briefing Paper. Kathmandu Metropolitan City, Nepal.

Pesticide Registration and Management Division (PRMD). (2009). Status of pesticides consumption in Nepal. Lalitpur, Nepal: Government of Nepal.

Pokhrel, D. M., \& Pant, K. P. (2008). Policy concern in organic farming promotion in Nepal. In P.

Chaudhary, K. Aryal, \& D. Tharu (Eds.), Proceedings of the International Workshop on Opportunities and Challenges of Organic Production and Marketing in South Asia, (pp. 143151), Nepal Permaculture Group, Kathmandu, Nepal.

Pradhan, P., \& Perera, R. (2005). Urban growth and its impact on the livelihoods of Kathmandu V alley, Nepal. Urban Management Programme for Asia and the Pacific, Urban Resource Network for Asia and Pacific.

Rajbhandari, B. P., \& Bhatta, G. D. (2008). Food cropsAgro-ecology and modern agro-techniques. Kathmandu, Nepal: HICAST Publications.

Schupp, A., \& Gillespie, J. (2001). Consumer attitudes towards potential country of origin labeling of fresh or frozen beef. Journal of Food Distribution Research, $32,34-44$.

Scialabba, N. (2000). Opportunities and constraints of organic agriculture: $A$ sociological analysis. Rome: FAO.

Shakya, D. B. (2005). Organic products: International market. In G. Sharma \& P. B. Thapa (Eds.), Proceeding of a National Workshop on Organic Agriculture 
and Farming System (pp. 145-157), Nepal

Permaculture Group, Kathmandu, Nepal.

Sharma, G. (2005). Organic agriculture in Nepal: An analysis into status, policy, technology and psychology. In G. Sharma \& P. B. Thapa (Eds.), Proceeding of a National Workshop on Organic Agriculture and Farming System (pp. 3-14), Nepal Permaculture Group, Kathmandu, Nepal.

Sharma, G. (2008). Ongoing Initiatives of Organic Agriculture in Nepal. In P. Chaudhary, K. Aryal, \& D. Tharu (Eds.), Proceedings of International Workshop on Opportunities and Challenges of Organic Production and Marketing in South Asia (pp. 140142), Nepal Permaculture Group, Kathmandu, Nepal.

Sherchan, D. P., Pilbeam, C. J., \& Gregory, P. J. (1999). Response of wheat-rice and maize/millet systems to fertilizer and manure applications in the mid-hills of Nepal. Experimental Agriculture, 35, 1-13. doi:10.1017/S0014479799001052

Shrestha, P., Koirala, P., \& Tamrakar, A. S. (2010). Knowledge, practice and use of pesticides among commercial growers of Dhading district, Nepal. Journal of Agriculture and Environment, 11, 95-100.

Smit, J., Ratta, A., \& Nasr, J. (1996). Urban agriculture: food, jobs and sustainable cities. Publication Series for UN Habitat II, vol. 1. New York: United Nations Development Programme (UNDP).

Souza, D. M., \& Ventura, M. (2001). Conjoint measurement of preferences for traditional cheeses in Lisbon. British Food Journal, 103, 414-424. doi:10.1108/00070700110400406

Swallow, B., Meinzen-Dick, R., \& van Noordwijk, M. (2005). Localizing demand and supply of environmental services: interaction with property rights, collective action and the welfare of the poor. CAPRi Working Paper \# 42. Washington, DC: IFPRI.
Thapa, R. B., \& Murayama, Y. (2010). Drivers of urban growth in the Kathmandu Valley, Nepal: Examining the efficacy of the analytical hierarchy process. Applied Geography, 30, 70-83. doi:10.1016/j.apgeog.2009.10.002

Thapa, R. B., Murayama, Y., \& Bajimaya, M. (2008). Kathmandu. Cities, 25, 45-57. doi:10.1016/i.cities.2007.10.001

Tobler, W. R. (1970). A computer movie simulating urban growth in the Detroit region. Economic Geography, 46 (Supplement)), 234-240.

Umoh, G. S. (2006). Resource use efficiency in urban farming: An application of stochastic frontier production function. International Journal of Agriculture \& Biology, 8(1), 38-44.

Vaidya, B. (2006, September). The Organic Scenario in Nepal. Paper presented in APO seminar on organic farming for sustainable development, Colombo, Sri Lanka.

Van Veenhuizen, R., \& Danso, G. (2007). Profitability and sustainability of urban and peri-urban agriculture. Rome: Food and Agriculture Organization (FAO).

Wachholtz, R. (1996). Socio-economics of Bedowin farming systems in dry areas of Northern Syria. Germany: Wissenschaftsverlag Vauk Kiel AG.

Weiss, J. (2004). Global organics: Co-opting a culture. Retrieved from http://Deliciouslivingmag.Com/ Greenliving/Dl Article 767/

Willer, H., \& Klicher, L. (2009). The world of organic agriculture. Statistics and Emerging Trends 2009. IFOAM, Bonn, FiBL, Frick, ITC, Geneva, retrieved from http://www.organic-world.net

Yves, C. (2004). Credit and financing for urban agriculture. Paper presented at the Workshop on IDRCSupported Initiatives on Urban Agriculture and Food Security, Ryerson University, Toronto. 